\title{
Directedness of soil-microbiological processes under the influence of organic and mineral fertilizers
}

\section{Volkogon V. ${ }^{1}$, Pyrig $0 .^{2}$, Brytan T. ${ }^{3}$}

Institute of agricultural microbiology and agroindustrial production of NAAS, Shevchenko Str., 97, Chernigiv, 14027, Ukraine; e-mail: ${ }^{1}$ volkogon@ukr.net, ${ }^{2}$ altrockman1986@gmail.com, ${ }^{3}$ britan.tetiana@gmail.com

The purpose. To study the influence of organic and mineral fertilizers on the development of microorganisms and dynamics of biological processes in soil at growing potato. Methods. Microbiological, field, statistical. Results. At importation into soil of organic fertilizers in the form of dung, straw, mass of lupin green manure crop, and their combinations with mineral fertilizers they observed descend essential changes in structure of microbiota and directedness of biological processes. Conclusions. Organic fertilizers and their combination with mineral ones promote optimization of formation of communities of soil microorganisms, dynamics of biological processes in soil. That positively influences productivity of potato. In ecological aspect, deficiency of organic substance in soil should be considered as undesirable at application of fertilizers because of increased gaseous losses of nitrogen and activity mineralization processes.

Key words: potato, organic fertilizers, mineral fertilizers, nitrogen fixation, denitrification, mineralization, conversion of organic substance, numerosity of microorganisms.

https://doi.org/10.31073/agrovisnyk201806-01

The main way to increase agricultural productivity is to increase the soil fertility. One of the most important factors determining the level of soil fertility is the organic matter of the soil and mainly humus. However, in intensive farming with the use of high doses of mineral fertilizers, the processes of mineralization of organic matter are significantly enhanced. As a result, many valuable qualities of soils are lost, which negatively affects their fertility in general. In this regard, the development of ways to maintain a stable level of organic matter content in the soil - an urgent task of agricultural science [1-5]. In order to understand the vectors of the destruction of fresh organic matter and the synthesis of humus, it is necessary to take into account the orientation of certain microbiological processes in the soil, depending on the technological factors.

The purpose of our research was to determine the impact of organic and mineral fertilizers on the development of microorganisms of certain ecological trophic groups and the course of biological processes in the soil during the cultivation of potatoes.

Materials and methods. The research was conducted in 2016-2017 years in stationary field experiment in the Institute of Agricultural Microbiology and agricultural production NAAS in leached black earth in short rotation (potato - barley - peas - winter wheat) in agrocenoses potatoes. Agrochemical characteristics of the soil: the content of humus (by Tyurin) $-2,8 \%$, total nitrogen - from $0,27 \%$ to $0.31 \%, \mathrm{P}_{2} \mathrm{O}_{5}$ (by Kirsanov) $-15 \mathrm{mg} / 100$ $\mathrm{g}$ of soil, $\mathrm{K}_{2} \mathrm{O}$ (according to Maslova) $-13 \mathrm{mg} / 100 \mathrm{~g}$ of soil; $\mathrm{pH}$ of water $-5,9-6,5$.

Potato fertilizer options: 1. Without fertilizers; 2. Straw; 3. Siderate; 4. Manure; 5. Straw + Siderate; 6. Manure + Siderate; 7. $\mathrm{N}_{40} \mathrm{P}_{40} \mathrm{~K}_{40} ; 8$. Straw + Siderate $+\mathrm{N}_{40} \mathrm{P}_{40} \mathrm{~K}_{40} ;$ 9. $\mathrm{N}_{80} \mathrm{P}_{80} \mathrm{~K}_{80} ;$ 10. Straw + Siderate $+\mathrm{N}_{80} \mathrm{P}_{80} \mathrm{~K}_{80}$; 11. $\mathrm{N}_{120} \mathrm{P}_{120} \mathrm{~K}_{120} ;$ 12. Straw + Siderate $+\mathrm{N}_{120} \mathrm{P}_{120} \mathrm{~K}_{120} ; 13$. Manure $+\mathrm{N}_{40} \mathrm{P}_{40} \mathrm{~K}_{40} ;$;4. Manure + Siderate $+\mathrm{N}_{40} \mathrm{P}_{40} \mathrm{~K}_{40}$.

Chopped straw for $5 \mathrm{t} /$ ha was imbedded in the soil by discarding immediately after harvesting of the predecessor winter wheat, after which, in appropriate variants, the lupine was sown on the intermediate siderate. To optimize the $\mathrm{C} /$ $\mathrm{N}$ ratio, mineral nitrogen was not used. Sideral mass of lupine (13 $\mathrm{t} / \mathrm{ha}$ ) imbedded in the soil by disking, followed by shallow plowing $(15 \mathrm{~cm})$ late autumn (end of November). At the same time, in appropriate variants, there was introduced and litter manure at the rate of $40 \mathrm{t} / \mathrm{ha}$.

The area of the experimental site is $43,2 \mathrm{~m}^{2}$; the repetition of the experiment is fourfold. 
The number of ammonizers was determined on meat-peptone agar (MPA); microorganisms, which mainly absorb mineral compounds of nitrogen - on starch-ammonia agar (SAA); nitrogen fixators - on a semi-liquid Ashby medium for use of acetylene test; denitrifiers - on a liquid Giltays medium for the use of a Grisse reagent; cellulose-destroying bacteria - on a Solntseva liquid medium; microscopic fungi - on the medium of Chapek [6, 7].

Coefficient of mineralization - immobilization of Nitrogen compounds were determined by the ratio of the number of amylolytic microorganisms to the protolithic (SAA / MPA) [8].

The potential activity of nitrogen fixation of the soil was determined by acetylene method for M.Umarov [9]. The ethylene content in the samples was analyzed on the Chrom- 5 gas chromatograph with a flame-ionization detector. Sorption columns from steel were filled with Porapak sorbent $Q$ 60-80 mesh. Thermostat temperature $40 \mathrm{C}$. Gas consumption: hydrogen $-15 \mathrm{~cm}^{3} / \mathrm{min}$, nitrogen $-100 \mathrm{~cm}^{3} / \mathrm{min}$, air $-500 \mathrm{~cm}^{3} / \mathrm{min}$.

The potential activity of denitrification in the soil was determined by the acetylene method when added to the lice (5d) solution of glucose and potassium nitrate [7]. We investigated the gas chromatograph "Color M-500" thermal conductivity detector (bridge current $200 \mathrm{~mA}$ ) column with sorbent Porapak Q 60-80 mesh. The temperature of the speakers is $25 \mathrm{C}$, the detector is $40 \mathrm{C}$, the gas (helium) flow is $20 \mathrm{ml} / \mathrm{min}$.

Planning and conducting field experiments were carried out for B. Dospehovy [10]. The statistical processing of experimental data was carried out by the method of dispersion analysis using a computer program (Microsoft Office Excel 2003 - 2007).

Results and discussion. Determination of the number of diazotrophs in the soil under potato for the effects of organic and mineral fertilizers indicates their different effects on the formation of nitrogen-fixing bacterial populations. So, the use of organic fertilizers positively affects the development of Nitrogen fixators - their number increases in 4,5-6,0 times. The low and average rate of fertilizers in the experiment also contributes to the increase in the number of diazotrophs in the soil, and especially - for their application on an organic background. The high rate of fertilizer causes the inhibition of the development of nitrogen fixing bacteria during the growing season of potato plants, which testifies to its redundancy for agrocenosis. At the same time, the introduction of $\mathrm{N}_{120} \mathrm{P}_{120} \mathrm{~K}_{120}$ on the background of action of organic fertilizers contributes to the restoration of development nitrogen fixators. This suggests improving the environment by these terms, as it is known that the development and function of nitrogen detent limited by excess mineral nitrogen in the soil.

This thesis is amplified by the results of determination of nitrogen activity in the soil of the studied variants (Table. 1). Nitrogen fixation in the variant using $\mathrm{N}_{120} \mathrm{P}_{120} \mathrm{~K}_{120}$ in the background of the organic matter is restored, starting with the flowering phase, and later even the control indicator values are substantially higher.

Table 1. Effect of fertilizers on the azophthixing activity of soil in agrocentoses of potatoes $n m o l C_{2} H_{4}$ /g soil per hour

\begin{tabular}{|l|c|c|c|}
\hline \multicolumn{1}{|c|}{ Experimental options } & $\begin{array}{c}\text { Phase } \\
\text { stairs }\end{array}$ & $\begin{array}{c}\text { Phase } \\
\text { flowering }\end{array}$ & $\begin{array}{c}\text { The phase of the } \\
\text { hedge deadening }\end{array}$ \\
\hline No fertilizer & 117,4 & 146,2 & 247,6 \\
\hline Straw & 161,5 & 243,7 & 395,2 \\
\hline Sidarate & 147,7 & 224,0 & 419,6 \\
\hline Manure & 271,6 & 298,1 & 565,9 \\
\hline Straw + Siderate & 197,1 & 260,6 & 477,2 \\
\hline Manure + Siderate & 321,7 & 397,4 & 589,5 \\
\hline $\mathrm{N}_{40} \mathrm{P}_{40} \mathrm{~K}_{40}$ & 148,5 & 203,8 & 377,0 \\
\hline Straw + Siderate $+\mathrm{N}_{40} \mathrm{P}_{40} \mathrm{~K}_{40}$ & 188,6 & 269,5 & 464,4 \\
\hline $\mathrm{N}_{80} \mathrm{P}_{80} \mathrm{~K}_{80}$ & 99,7 & 198,6 & 302,5 \\
\hline Straw + Siderate $+\mathrm{N}_{80} \mathrm{P}_{80} \mathrm{~K}_{80}$ & 162,8 & 229,7 & 392,6 \\
\hline $\mathrm{N}_{120} \mathrm{P}_{120} \mathrm{~K}_{120}$ & 43,6 & 115,3 & 210,7 \\
\hline
\end{tabular}




\begin{tabular}{|l|c|c|c|}
\hline Straw + Siderate $+\mathrm{N}_{120} \mathrm{P}_{120} \mathrm{~K}_{120}$ & 69,8 & 148,8 & 323,3 \\
\hline Manure $+\mathrm{N}_{40} \mathrm{P}_{40} \mathrm{~K}_{40}$ & 212,6 & 365,2 & 508,2 \\
\hline Manure + Siderate $+\mathrm{N}_{40} \mathrm{P}_{40} \mathrm{~K}_{40}$ & 289,6 & 406,4 & 566,5 \\
\hline LLD 05 & 11,2 & 10,3 & 11,5 \\
\hline
\end{tabular}

In determining the number of denitrifiers, there is no increase in the number of representatives of this ecological trophic group of microorganisms for the introduction of straw. A small increase in the number of denitrifying microorganisms in the soil is observed in variants using the seed mass and its combination with straw. In the course of manure, intense development of denitrification was noted. This indicates the active mineralization of organic matter and the release of mineral compounds of nitrogen, some of which can, under certain circumstances, be used as denitrification sources as an oxygen source and nitrogen (for both assimilation and dissimilation nitrate reduction).

For the introduction of mineral fertilizers, the number of denitrifiers in the soil increases in proportion to the norms used. However, using fertilizers against the background of the effect of organic fertilizers reduces the situation - in these conditions, the number of representatives of the studied group of bacteria decreases, which undoubtedly indicates the immobilization of other ecological trophic groups of microorganisms unused plants part of fertilizers.

This is confirmed by the results of determining the potential denitrification activity in the soil (Table. 2).

Table 2. Potential activity of denitrification of soil under potato under the influence of fertilizers, $\mathrm{nMol}$ $\mathrm{N}_{2} \mathrm{O} / \mathrm{g}$ soil per day

\begin{tabular}{|l|c|c|c|}
\hline \multicolumn{1}{|c|}{ Experimental options } & $\begin{array}{c}\text { Phase } \\
\text { stairs }\end{array}$ & $\begin{array}{c}\text { Phase } \\
\text { flowering }\end{array}$ & $\begin{array}{c}\text { The phase of the } \\
\text { hedge deadening }\end{array}$ \\
\hline No fertilizer & 28,20 & 22,54 & 20,06 \\
\hline Straw & 29,15 & 23,05 & 20,87 \\
\hline Sidarate & 37,58 & 28,25 & 23,43 \\
\hline Manure & 78,30 & 66,07 & 49,20 \\
\hline Straw + Siderate & 35,33 & 27,19 & 22,63 \\
\hline Manure + Siderate & 61,74 & 56,89 & 38,34 \\
\hline $\mathrm{N}_{40} \mathrm{P}_{40} \mathrm{~K}_{40}$ & 43,77 & 37,39 & 32,96 \\
\hline Straw + Siderate $+\mathrm{N}_{40} \mathrm{P}_{40} \mathrm{~K}_{40}$ & 40,96 & 32,05 & 29,53 \\
\hline $\mathrm{N}_{80} \mathrm{P}_{80} \mathrm{~K}_{80}$ & 51,73 & 44,43 & 34,03 \\
\hline Straw + Siderate $+\mathrm{N}_{80} \mathrm{P}_{80} \mathrm{~K}_{80}$ & 47,79 & 39,99 & 30,21 \\
\hline $\mathrm{N}_{120} \mathrm{P}_{120} \mathrm{~K}_{120}$ & 63,76 & 58,78 & 40,12 \\
\hline Straw + Siderate $+\mathrm{N}_{120} \mathrm{P}_{120} \mathrm{~K}_{120}$ & 55,69 & 46,26 & 38,47 \\
\hline Manure + $\mathrm{N}_{40} \mathrm{P}_{40} \mathrm{~K}_{40}$ & 91,19 & 80,00 & 62,84 \\
\hline Manure + Siderate $+\mathrm{N}_{40} \mathrm{P}_{40} \mathrm{~K}_{40}$ & 88,92 & 73,76 & 56,51 \\
\hline LLD 05 & 1,95 & 1,67 & 1,88 \\
\hline
\end{tabular}

For the combination of organic and mineral fertilizers of potatoes, the activity of the biological denitrification process decreases in comparison with the parameters of the variants, in which only mineral fertilizers were introduced in the appropriate norms. This situation, as already noted above, may arise due to the significant immobilization of unused mineral nitrogen by soil microorganisms.

According to the results of the number of ammonium microorganisms, their significant development is stipulated to the presence of organic matter in the soil. Thus, the number of ammonifiers in variants, which 
combines the action of mineral and organic fertilizers, grows in comparison with the indicators of the appropriate variants, using only fetilizer in 1,8-2,6 times (Table. 3). At the same time, the growth compared with the control of the number of ammonifiers in variants using only mineral fertilizers can indicate the mineralization of complex organic compounds, including humus with deficit of organic matter in the soil.

The determination of the number of microorganisms that assimilate the mineral nitrogen compounds is indicative of an increase in their number in all investigated variants, especially with the use of manure both separately and in combination with siderate and mineral fertilizers (Table 3).

It should also be noted that a significant number of microorganisms of the specified eco-trophic group in variants with the consistent application of straw and siderate against the background of mineral fertilization.

In variants with mineral fertilizers only, the growth of a pool of mineral nitrogen immobilizers on the background of a small amount of ammonifiers indicates an increase in the mineralization function of microbial cenosis, which is confirmed by an increase in the coefficients of mineralization-immobilization in the flowering phase from 1,86 at a dose of $\mathrm{N}_{40} \mathrm{P}_{40} \mathrm{~K}_{40}$ to 2,42 at dose $\mathrm{N}_{120} \mathrm{P}_{120} \mathrm{~K}_{120}$. However, the action of straw and siderate for the introduction of mineral fertilizers provided a reduction of the negative effects of the intensification of nitrogen fertilizer potatoes. Within these conditions, the the coefficient of mineralization-immobilization was 1,20 at a dose of $\mathrm{N}_{40} \mathrm{P}_{40} \mathrm{~K}_{40}$ and 1,23 at a dose of $\mathrm{N}_{120} \mathrm{P}_{120} \mathrm{~K}_{120}$.

For a separate use of straw and siderate, the increase in the number of microorganisms assimilating the mineral forms of nitrogen, compared with other variants, was negligible. However, the coefficient of mineralization -immobilization was lower than in the control and was in the phase of flowering $1.60-1.36$, respectively, which may indicate an intensification of the processes of immobilization (synthesis).

In other variants of the experiment, there was a significant decrease in the coefficients of mineralizationimmobilization - from 1,15 for the combined application of manure and mineral fertilizers to 1,07 - in the variant with the combined application of manure, siderate and low dose of mineral fertilizers.

We made conclusions about the intensive development of microorganisms and the optimization of the processes of mineralization-immobilization for the use of mineral fertilizers in the background of organic action are confirmed by the results of the accounting of cellulosolytic microorganisms. Thus, for the introduction of only mineral fertilizers, relatively low indicators of cellulosolytic bacteria development were marked, which decrease with increasing rates of fertilizes (Table 4). However, application of mineral fertilizers against the background of the action of organic matter facilitates their growth for 2,4-4,1 times depending on the variant.

It should be noted that the marked decrease in the number of cellulosic bacteria, as the fertilizer rates increase, is offset by an increase in the number of micromycetes, most of which are known to possess high cellulolytic activity. The results show that the growth of norms of mineral fertilizers is accompanied by a significant increase in the number of micromycetes.

Taking into account the above-mentioned results of counting the number of microorganisms and the nature of the processes of nitrogen fixation and denitrification, we can also argue that strengthening of immobilization processes for the use of organo-mineral fertilizers. 


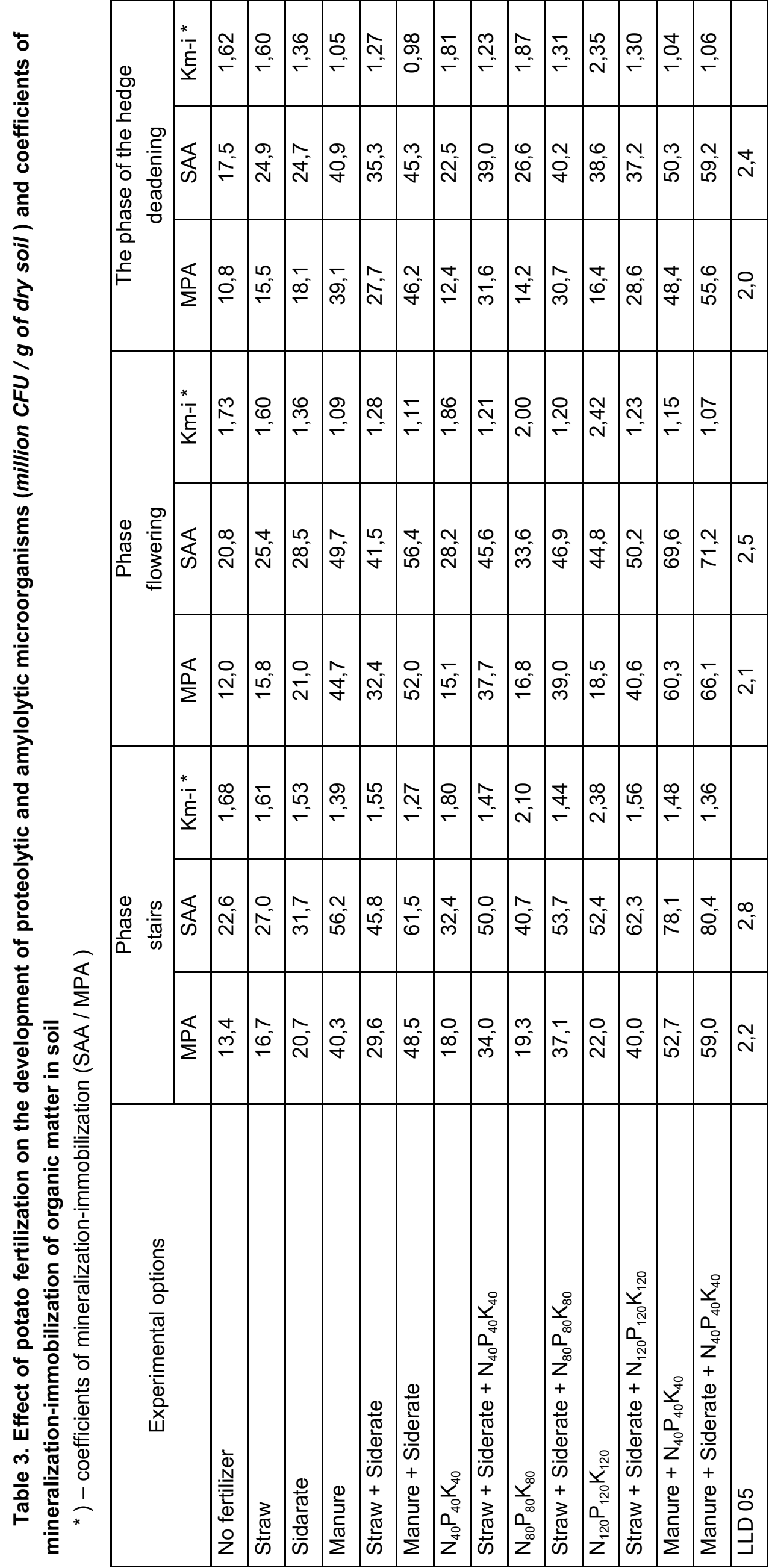


In other words, for the combination of organic and mineral fertilizers because of mineralization of complex organic substances, simple compounds were formed, some of which are capable of digestion by microorganisms and, accordingly, immobilized in biomass of bacteria and micromycetes. This creates the preconditions for the active development of other synthetic processes, including the formation of humus compounds.

Table 4. Number of cellulosicidal bacteria in soil under potatoes, depending on fertilization, ths. / $g$ of dry soil

\begin{tabular}{|l|c|c|c|}
\hline \multicolumn{1}{|c|}{ Experimental options } & $\begin{array}{c}\text { Phase } \\
\text { stairs }\end{array}$ & $\begin{array}{c}\text { Phase } \\
\text { flowering }\end{array}$ & $\begin{array}{c}\text { The phase of the } \\
\text { hedge deadening }\end{array}$ \\
\hline No fertilizer & 18,1 & 15,8 & 12,4 \\
\hline Straw & 44,8 & 38,7 & 25,2 \\
\hline Sidarate & 31,4 & 26,6 & 21,5 \\
\hline Manure & 94,3 & 88,9 & 80,3 \\
\hline Straw + Siderate & 55,4 & 42,8 & 35,8 \\
\hline Manure + Siderate & 101,2 & 91,8 & 87,3 \\
\hline $\mathrm{N}_{40} \mathrm{P}_{40} \mathrm{~K}_{40}$ & 26,4 & 24,7 & 20,8 \\
\hline Straw + Siderate $+\mathrm{N}_{40} \mathrm{P}_{40} \mathrm{~K}_{40}$ & 63,2 & 59,6 & 50,8 \\
\hline $\mathrm{N}_{80} \mathrm{P}_{80} \mathrm{~K}_{80}$ & 22,2 & 19,1 & 15,8 \\
\hline Straw + Siderate $+\mathrm{N}_{80} \mathrm{P}_{80} \mathrm{~K}_{80}$ & 59,4 & 48,8 & 42,9 \\
\hline $\mathrm{N}_{120} \mathrm{P}_{120} \mathrm{~K}_{120}$ & 19,6 & 16,8 & 12,2 \\
\hline Straw + Siderate $+\mathrm{N}_{120} \mathrm{P}_{120} \mathrm{~K}_{120}$ & 51,4 & 47,2 & 39,4 \\
\hline Manure + $\mathrm{N}_{40} \mathrm{P}_{40} \mathrm{~K}_{40}$ & 97,1 & 90,8 & 84,2 \\
\hline Manure + Siderate $+\mathrm{N}_{40} \mathrm{P}_{40} \mathrm{~K}_{40}$ & 107,6 & 99,7 & 88,7 \\
\hline
\end{tabular}

Thus, providing chernozem effluent with organic matter (manure, straw, lupine siderate and their combination, including mineral fertilizers) in growing potatoesin crop rotation substantially affects the composition of groups of soil micro organisms, which changes the orientation of biological processes. Under such conditions, the mineralization of complex organic compounds is accompanied by optimization of other biological functions of the soil - the intensity of nitrogen fixation increases, denitrification activity is limited, synthetic processes are amplified.

The greatest experiment in the rate of fertilizer $\left(\mathrm{N}_{120} \mathrm{P}_{120} \mathrm{~K}_{120}\right)$, which shall be accompanied by negative changes in biological processes in the soil, it is environmentally acceptable.

Influence of investigated factors affected the productivity of potatoes (Table 5).

Table 5. The yield of potato under different fertilizer systems

\begin{tabular}{|l|c|c|c|}
\hline \multirow{2}{*}{ Experimental options } & \multirow{2}{*}{ Yield, t/ha } & \multicolumn{2}{c|}{ Increase to control } \\
\cline { 3 - 4 } & & t/ha & $\%$ \\
\hline No fertilizer & 12,9 & - & - \\
\hline Straw & 14,1 & 1,2 & 9,3 \\
\hline Sidarate & 15,4 & 2,5 & 19,3 \\
\hline Manure & 25,0 & 12,1 & 93,8 \\
\hline Straw + Siderate & 18,6 & 5,7 & 44,2 \\
\hline Manure + Siderate & 27,1 & 14,2 & 110,0 \\
\hline
\end{tabular}




\begin{tabular}{|l|c|c|c|}
\hline $\mathrm{N}_{40} \mathrm{P}_{40} \mathrm{~K}_{40}$ & 15,0 & 2,1 & 16,3 \\
\hline Straw + Siderate $+\mathrm{N}_{40} \mathrm{P}_{40} \mathrm{~K}_{40}$ & 23,8 & 10,9 & 84,5 \\
\hline $\mathrm{N}_{80} \mathrm{P}_{80} \mathrm{~K}_{80}$ & 25,2 & 12,3 & 95,3 \\
\hline Straw + Siderate $+\mathrm{N}_{80} \mathrm{P}_{80} \mathrm{~K}_{80}$ & 33,3 & 20,4 & 158,1 \\
\hline $\mathrm{N}_{120} \mathrm{P}_{120} \mathrm{~K}_{120}$ & 32,5 & 19,6 & 151,9 \\
\hline Straw + Siderate $+\mathrm{N}_{120} \mathrm{P}_{120} \mathrm{~K}_{120}$ & 39,1 & 26,2 & 203,1 \\
\hline Manure $+\mathrm{N}_{40} \mathrm{P}_{40} \mathrm{~K}_{40}$ & 30,0 & 17,1 & 132,5 \\
\hline Manure + Siderate $+\mathrm{N}_{40} \mathrm{P}_{40} \mathrm{~K}_{40}$ & 32,8 & 19,9 & 154,2 \\
\hline LLD 05 & 0,98 & & \\
\hline
\end{tabular}

The application of all the studied standards of mineral fertilizers provided a significant increase in the productivity of the crop. However, the use of fertilizes against the background of the effects of organic fertilizers contributed to a significantly higher yield. Thus, for the introduction of $\mathrm{N}_{40} \mathrm{P}_{40} \mathrm{~K}_{40}$, the growth of the crop was $16,3 \%$, and the use of this norm of straw in the background of the action of straw and siderate provided an increase of $84,5 \%$; for the introduction of the average fertilizer norm in the experiment $\left(\mathrm{N}_{80} \mathrm{P}_{80} \mathrm{~K}_{80}\right)$, the yield of the crop increased by $95,3 \%$, and for the combination of it with organic background - by $158,1 \%$. The same characteristics can be traced to the largest volumes of the test in the experiment - the use of mineral fertilizers only contributed to the production of $32,5 \mathrm{t} / \mathrm{ha}$ of potatoes, and, in combination with the organic background, the yield increased by $6,6 \mathrm{t} / \mathrm{ha}$.

Thus, the action of organic fertilizers, including their combination with mineral, helps to optimize the formation of groups of soil microorganisms, the flow of biological processes in black soil effluent and positively affects the productivity of potatoes. From an environmental point of view, the use of mineral fertilizers for the lack of organic matter in the soil should be considered inadmissible, since it increases gaseous nitrogen losses and increases the activity of mineralization of these processes.

\section{Conclusions}

Organic fertilizers and their combination with mineral ones promote optimization of formation of communities of soil microorganisms, dynamics of biological processes in soil. That positively influences productivity of potato. In ecological aspect, deficiency of organic substance in soil should be considered as undesirable at application of fertilizers because of increased gaseous losses of nitrogen and activity mineralization processes.

\section{Reference}

1. Matjuk N.S. Selickaja O.V., Soldatova S.S. (2013). Rol' sideratov i solomy v stabilizacii processov transformacii organicheskogo veshhestva $v$ dernovo-podzolistoj pochve. [The role of siderates and straw in stabilizing processes of transformation of organic matter in soddy podzolic soils]. Izvestija TSHA. Vyp. 3. P. 6374. [in Russian].

2. Shhapova L.N. (2004). Mikrobnaja sukcessija pri transformacii organicheskogo veshhestva. [Microbial succession in the transformation of organic matter]. Pochvovedenie. № 8. P. 967-975. [in Russian].

3. Zinchenko M.K., Stojanova L.G. (2015). Bakterii azotnogo obmena kak indikatory processov transformacii organicheskogo veshhestva $v$ agrolandshaftah seroj lesnoj pochvy. [Bacteria of nitrogen metabolism as indicators of transformation processes of organic matter in agrolandscapes of gray forest soil]. Vladimirskij Zemledelec. 2015. № 2. P. 8-11. [in Russian].

4. Ademir S.F.A., Luiz F.C. L, Valdinar B.S., Romero F.V.C. (2009). Soil microbial activity in conventional and organic agricultural systems. Sustainability. 2009. № 1. P. 268-276.

5. Mader P., Fliessbach A., Dubois D. et. al. (2002). Soil fertility and biodiversity in organic farming. Science. 2002. № 296. P. 1694-1697.

6. Volkohon V.V., Nadkernychna O.V., Tok-makova L.M. ta in. (Volkohon V.V. Ed.). (2010). Eksperymentalna gruntova mikrobiolohiia: monohrafiia. [Experimental Soil Microbiology: Monograph ]. Kyiv: Ahrarna nauka, 2010. 464 p. [in Ukrainian] 
7. Aseeva I.V., Bab'eva I.P., Byzov B.A. et al. (Zvjagincev D.G. Ed.). (1991). Metody pochvennoj mikrobiologii i biohimii [Methods of soil microbiology and biochemistry]. Moskva: MGU, 1991. 304 c. [in Russian].

8. Mishustin E.N., Runov E.V. (1957). Uspehi razrabotki principov mikrobiologicheskogo diagnostirovanija sostojanija pochv. Uspehi sovremennoj biologii. [The success of the development of the principles of microbiological diagnosis of soil condition]. Moskva: AN SSSR. T. 44. C. 256-267. [in Russian].

9. Umarov M.M. (1976). Acetilenovyj metod izuchenija azotfiksacii v pochvenno-mikrobiologicheskih issledovanijah. [The success of the development of the principles of microbiological diagnosis of soil condition]. Pochvovedenie. № 11. C. 119-123. [in Russian].

10. Dospehov B.A. (1985). Metodika polevogo opyta s osnovami statisticheskoj obrabotki rezul'tatov issledovanij. [The success of the development of the principles of microbiological diagnosis of soil condition]. Moskva: Agropromizdat, 1985. 351 c. [in Russian]. 